\title{
Detection of Flowering Leafy Spurge With Satellite Multispectral Imagery
}

\author{
E. Raymond Hunt, Jr. ${ }^{1}$ and Amy E. Parker Williams ${ }^{2}$ \\ Authors are ${ }^{1}$ Research Physical Scientist, USDA-ARS Hydrology and Remote Sensing Laboratory, Beltsville, MD 20705; and \\ ${ }^{2}$ Research Associate, Department of Botany, University of Wyoming, Laramie, WY 82071.
}

\begin{abstract}
The distribution and abundance of flowering leafy spurge (Euphorbia esula L.) can be determined with hyperspectral remote sensing, but the availability of hyperspectral sensors is limited. Hence, the Landsat 7 Enhanced Thematic Mapper Plus (ETM+) and System Pour d'Observation de la Terre (SPOT) 4 imagery were acquired to test the ability of these sensors to detect leafy spurge. The green:red band ratio was the vegetation index with the highest correlations to flowering leafy spurge cover, but the correlations were weak and not useful for predictions. With Airborne Visible Infrared Imaging Spectrometer (AVIRIS) data, the green:red band ratio was also weakly correlated to flowering leafy spurge cover, although the output from a hyperspectral unmixing algorithm was highly correlated with cover using the same data, indicating simple indices have limited power for detecting leafy spurge. Canopy reflectance modeling using the Scattering by Arbitrarily Inclined Leaves (SAIL) model suggests the weak correlations were caused by variations in leaf area index. It is important to develop spectral libraries in order to use canopy reflectance simulation models that can reduce the time and effort of remote sensing analysis for detecting leafy spurge and other invasive weeds.
\end{abstract}

\section{Resumen}

La distribución y abundancia del leafy spurge florecimento (Euphorbia esula L.) puede ser determinada con sensores remotos hiperespectrales, pero la disponibilidad de estos sensores es limitada. Se adquirieron imágenes de Landsat 7 Enhanced Thematic Mapper Plus (ETM+) y System Pour d'Observation de la Terre (SPOT) 4 para evaluar la capacidad de estos sensores para detectar el leafy spurge. La relación de banda verde:roja fue el índice de vegetación con las correlaciones más altas con relación a la cobertura de leafy spurge florecimento, pero las correlaciones fueron débiles y sin utilidad para realizar predicciones. Con datos del Airborne Visible Infrared Imaging Spectrometer (AVIRIS) la relación de banda verde:roja también estuvo débilmente correlacionada con la cobertura del leafy spurge florecimento, aunque, cuando se usaron los mismos datos, el resultado de un algoritmo hiperespectral no mezclado estuvo altamente correlacionado con la cobertura, indicando que índices simples tienen un poder limitado para detectar el leafy spurge florecimento. Al modelar la reflexión de la copa usando el modelo de Dispersión por las Hojas Inclinadas Arbitrariamente (SAIL), el modelo sugiere que las correlaciones débiles fueron causadas por variaciones en el índice de área foliar. Es importante desarrollar bibliotecas espectrales para usar modelos de simulación de reflexión de la copa que puedan reducir el tiempo y esfuerzo del análisis de sensores remotos para detectar el leafy spurge florecimento y otra malezas invasoras.

Key Words: Euphorbia esula L., invasive species, Landsat 7 ETM+, SPOT, hyperspectral imagery, AVIRIS, vegetation indices, SAIL canopy model, spectral libraries

\section{INTRODUCTION}

Mapping the distribution and abundance of leafy spurge (Euphorbia esula L.) over large areas on the ground can be prohibitively expensive, even when compared to the annual economic costs of leafy spurge infestations (Anderson et al. 2003). Remote sensing imagery may provide a low-cost alter-

Research was funded in part by USDA-ARS TEAM Leafy Spurge and the Wyoming Space Grant Consortium.

At the start of the research, the authors were assistant professor (E.R.H.) and graduate research assistant (A.E.P.W.) in the Department of Botany, University of Wyoming, Laramie, WY 82071.

Correspondence: E. Raymond Hunt, Jr., USDA-ARS Hydrology and Remote Sensing Laboratory, Building 007 Room 104, 10300 Baltimore Ave, Beltsville, MD 20705-2350. Email: erhunt@hydrolab.arsusda.gov

Manuscript received 6 December 2005; manuscript accepted 21 February 2006. native (Tueller 1989, 1995; Everitt et al. 1995, 2001, 2002; Hunt et al. 2003). For leafy spurge, the reflectance spectrum of flower bracts is different from that of leaves, because of high reflectances at green and yellow wavelengths (Fig. 1). Hunt et al. (2004) showed that the yellow-green color of the flower bracts is due to low amounts of chlorophyll and carotenoids in a 1:1 concentration ratio. Hyperspectral remote sensing or imaging spectroscopy uses sensors such as the Airborne Visible Infrared Imaging Spectrometer (AVIRIS) that have many contiguous, narrow bands, which can be used to obtain the reflectance spectrum of a pixel (Green et al. 1998). Hyperspectral imagery can detect the presence of flowering leafy spurge based on its reflectance (O'Neill et al. 2000; Parker Williams and Hunt 2002, 2004; Glenn et al. 2005). Hyperspectral imagery would be ideal to map the distribution and abundance of leafy spurge, except that the area covered is small, data are not routinely available, and analyses require considerable expertise. 
Multispectral remote sensing uses a few, discreet bands that cover a broad wavelength region. Two multispectral sensors on satellite platforms are the Enhanced Thematic Mapper Plus $(\mathrm{ETM}+)$ onboard the Landsat 7 satellite and the System Pour d'Observation de la Terre (SPOT) 4 sensor/satellite (Fig. 1). Landsat ETM+ has bands in the visible $(400-700 \mathrm{~nm})$, nearinfrared (700-1100 nm), and shortwave-infrared wavelengths $(1100-2500 \mathrm{~nm})$ with a pixel size of $900 \mathrm{~m}^{2}$ (Fig. 1). Landsat ETM+ also has bands in the thermal infrared (band 6), and a panchromatic (band 8). SPOT 4 has 4 bands with a pixel size of $400 \mathrm{~m}^{2}$ (Fig. 1). The advantages of multispectral imagery are that these data are routinely available, there are several software packages for handling the data, and expertise with data analysis and image-processing software are more common. With bands available on multispectral sensors, it should be possible to detect the distinctive yellow-green color of leafy-spurge flower bracts.

The objective of this study was to use ground data acquired by Parker Williams and Hunt (2002 and 2004) to test the ability of vegetation indices with Landsat ETM+ and SPOT 4 imagery to detect the presence and determine the abundance of flowering leafy spurge. Also, the results were compared to the same indices using narrow bands from the AVIRIS imagery. A canopy reflectance model with a spectral library was used to determine the best bands or combination of bands to determine the amount of flowering leafy spurge present in the study area.

\section{MATERIALS AND METHODS}

\section{Study Area}

The area for this study was The Ecological Area-wide Management of (TEAM) Leafy Spurge site near Devils Tower National Monument in Crook County, Wyoming (Parker Williams 2001; Parker Williams and Hunt 2002, 2004). The site was $44.4^{\circ}-44.6^{\circ} \mathrm{N}$ latitude and $104.6^{\circ}-104.9^{\circ} \mathrm{W}$ longitude. Elevations ranged from $1219 \mathrm{~m}$ along the Bell-Fourche River to $1584 \mathrm{~m}$ at the Missouri Buttes. The vegetation cover types in the study area were a mosaic of conifer woodlands, northern mixed-grass prairie, and riparian zones with deciduous shrubs and trees. Leafy spurge was well established throughout the study area.

The period of leafy spurge bract formation in 1999 began in late June and lasted until mid-July (approximately 3 weeks). All of the ground data collection occurred during this period (Parker Williams 2001; Parker Williams and Hunt 2002, 2004). Two sets of plots were established in the study area using a 1991 Landsat 5 Thematic Mapper image. The plots in the first set were circular $(46 \mathrm{~m}$ diameter) and the cover of flowering leafy spurge was measured in each plot (Parker Williams and Hunt 2002). Plots in the second set were rectangular $(50 \times 50 \mathrm{~m})$ and the presence or absence of flowering leafy spurge was determined for each plot (Parker Williams and Hunt 2004). Because all plots in the first set had some leafy spurge (>5\% cover), and cover was not measured for the second set of plots, we combined the spurge-absent plots from the second set with the first set to increase the number of plots.

\section{Canopy Reflectance Modeling}

The Scattering by Arbitrarily Inclined Leaves (SAIL) model was designed to predict canopy reflectance for various leaf area

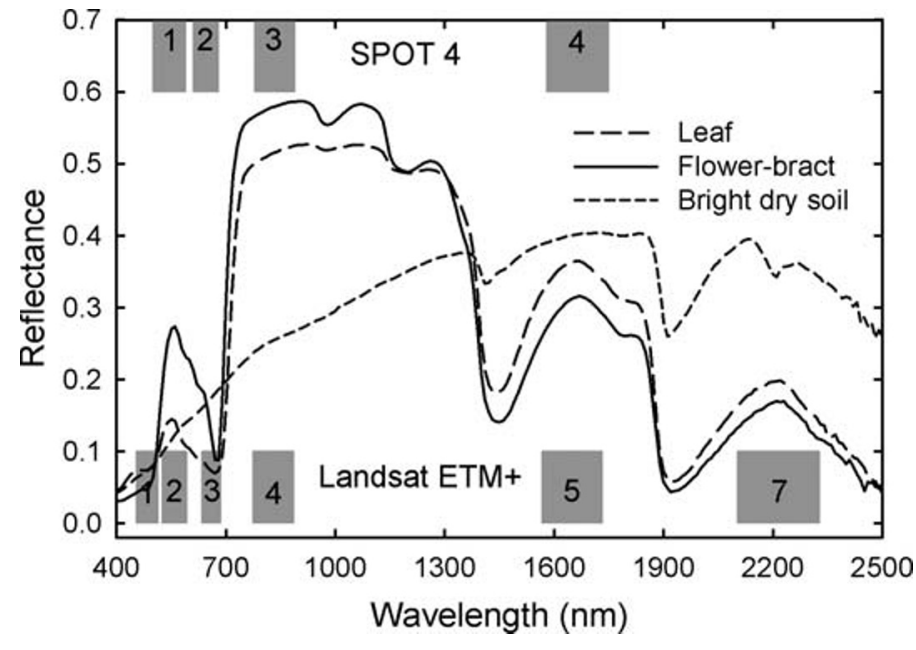

Figure 1. Spectral reflectances of leafy spurge flower-bracts, leafy spurge leaves, and bare soil. The band positions of Landsat 7 Enhanced Thematic Mapper Plus (ETM+) and System Pour d'Observation de la Terre (SPOT) 4 sensors are shown; Airborne Visible InfraRed Imaging Spectrometer (AVIRIS) has 224 contiguous bands covering the range of 400-2 $500 \mathrm{~nm}$.

indices (LAI) and measured leaf reflectance and transmittance (Verhoef 1984). The SAIL model can have multiple canopy layers and multiple components within each canopy layer. The key parameters are solar elevation and azimuth (from declination and time of day) and ground surface reflectance. Along with LAI and leaf optical properties, the fraction of leaves in $10^{\circ}$-angle increments is required for leaf angle distribution.

The computer code version of the SAIL model used in this study was originally created by Lynn Alexander (Alexander 1983) and modified by Moon Kim (Daughtry et al. 2000) for the Microsoft-DOS operating system. A graphical user interface for the Microsoft Windows operating system was programmed in Visual Basic and is available from the corresponding author.

The soil, leaf and flower-bract spectral reflectances (Hunt et al. 2004) were used as inputs to the SAIL model (Fig. 1). The leaf and flower-bract transmittance spectra were not measured (Hunt et al. 2004); therefore, it was assumed that the transmittance was proportional to reflectance from 400-2 $500 \mathrm{~nm}$, such that the minimum absorptance in the near-infrared was $2 \%$ (Daughtry et al. 2000). Grass and forb reflectance and transmittance spectra were obtained from measurements on Festuca arundinacea Schreb. (tall fescue) and Taraxacum officinale F. H. Wigg. aggr. (dandelion), respectively. Leafy spurge flower bracts and leaves and forb leaves were assumed to have a typical planophile (horizontal) leaf distribution, and grass leaves were assumed to have a typical erectophile (vertical) leaf distribution.

\section{Image Analysis and Vegetation Indices}

The Airborne Visible Infrared Imaging Spectrometer (AVIRIS) (Green et al. 1998) operated by the National Aeronautics and Space Administration (NASA) Jet Propulsion Laboratory (JPL) (Pasadena, CA) was flown at high altitude (pixel size of $20 \times 20 \mathrm{~m}$ ) over the study site on 6 July 1999 (Parker Williams and Hunt 2002). The AVIRIS data were atmospherically corrected using the ATREM 3.1 program (Gao et al., 1993, 


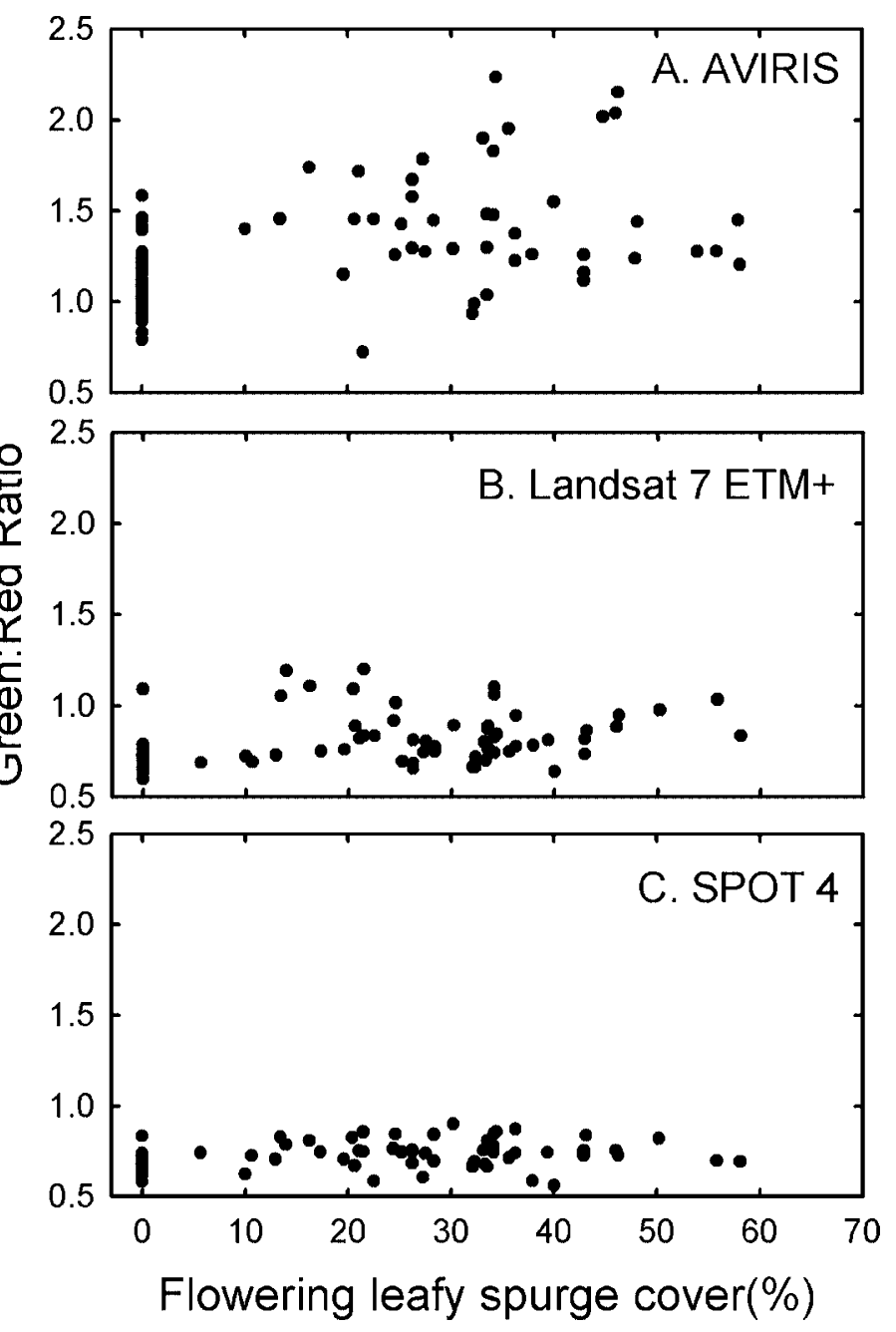

Figure 2. Green:red reflectance ratio versus measured flowering leafy spurge cover in the prairie land cover type for A, Airborne Visible InfraRed Imaging Spectrometer (AVIRIS), B, Landsat 7 Enhanced Thematic Mapper Plus (ETM+), and C, System Pour d'Observation de la Terre (SPOT) 4 sensors.

1999). Spectral reflectances from 350-1 $100 \mathrm{~nm}$ were measured over a large talus field at the base of Devils Tower using an ASD FieldSpec UV/VNIR spectroradiometer (Analytical Spectral Devices, Inc, Boulder, CO). The AVIRIS data were further corrected using the mean reflectance spectrum of the talus field (Parker Williams and Hunt 2002).

The reflectance spectrum of a pixel is an area-weighted mixture of the individual components, called endmembers. If the spectral reflectances of the endmembers are known, then the amount of each component within a pixel can be calculated using various spectral-unmixing algorithms. The number of endmembers that can be identified is limited by the number of spectral bands, so spectral-unmixing algorithms are often used with hyperspectral data, such as AVIRIS. Mixture Tuned Matched Filtering (MTMF) is a spectral-unmixing algorithm constrained by an infeasibility score (Harsanyi and Chang 1994; Boardman et al. 1995; Boardman 1998; RSI 1999). The advantage of MTMF is that only a single, unique endmember is used, so this algorithm is particularly useful for detection of flowering leafy spurge (Parker Williams and Hunt 2002, 2004).
A Landsat 7 ETM+ image (path 35 row 29, pixel size $30 \times 30 \mathrm{~m}$ ) was acquired on 8 July 1999, which was before the failure of the Scanning Line Corrector. The study area was on the extreme eastern boundary of the ETM+ image. Although the image was registered to the UTM map projection by the US Geological Survey (USGS) Earth Resources Observation Systems (EROS) Data Center, the registration was not accurate to one pixel, so an image to map registration was performed using ground control points from a 1:24 000 USGS topographic map. The root mean square error of the registered image was $26 \mathrm{~m}$, within a single Landsat ETM+ pixel.

A SPOT 4 image (pixel size $20 \times 20 \mathrm{~m}$ ) centered on Devils Tower was acquired on 11 July 2000, a year after data collection. Originally a SPOT image was acquired on 9 July 1999, but the gain was set too high, hence the digital values were saturated for large portions of the image. The 2000 image was registered to map coordinates using the Landsat 7 ETM+ image and additional ground control points.

The digital values of the ETM+ and SPOT 4 images are radiances at the satellite, whereas reflectances are required for comparison with the SAIL model results. Bands 1 through 4 of the Landsat ETM+ image and bands 1 through 3 of the SPOT 4 image (Fig. 1) were corrected to reflectance using the mean reflectance spectrum of the talus field. Because the spectroradiometer did not measure reflectance beyond $1100 \mathrm{~nm}$, the shortwave-infrared bands (bands 5 and 7 of Landsat ETM+ and band 4 of SPOT 4; Fig. 1) were atmospherically corrected using the reflectances predicted for the talus field from the ATREM model.

A standard technique with multispectral imagery is the use of vegetation indices. Based on the spectral differences of leafy spurge leaves and flower bracts, several indices were tested with the AVIRIS, ETM+, and SPOT 4 imagery. The first index evaluated was the Normalized Difference Vegetation Index (NDVI) (Rouse et al. 1974):

$$
\mathrm{NDVI}=(\mathrm{NIR}-\mathrm{Red}) /(\mathrm{NIR}+\mathrm{Red})
$$

where NIR was AVIRIS band 54, ETM+ band 4, or SPOT band 3, and Red was AVIRIS band 31, ETM+ band 3, or SPOT band 2 (Fig. 1). The second index evaluated was the Green Normalized Difference Vegetation Index (GNDVI):

$$
\text { GNDVI }=(\mathrm{NIR}-\text { Green }) /(\mathrm{NIR}+\text { Green })
$$

where Green was AVIRIS band 20, ETM+ band 2, or SPOT band 1 (the NIR band was defined in Eq. 1). The GNDVI was used because it is more sensitive to plant chlorosis than NDVI (Gitelson et al. 1996), hence it should be more sensitive to the yellow-green flower bracts. The third index evaluated was the Green to Red reflectance ratio (G/R):

$$
\mathrm{G} / \mathrm{R}=\text { Green } / \text { Red }
$$

where green and red bands were defined in Equations 2 and 1 , respectively. Normalized difference and ratio indices are related, however the relationship is nonlinear (e.g., the normalized difference between the green and red bands [green $-\mathrm{red}] /[$ green + red] is equal to $[\mathrm{G} / \mathrm{R}-1] /[\mathrm{G} / \mathrm{R}+1]$ ). Thus, the choice between the two types of indices for a given set of bands is a matter of preference. 


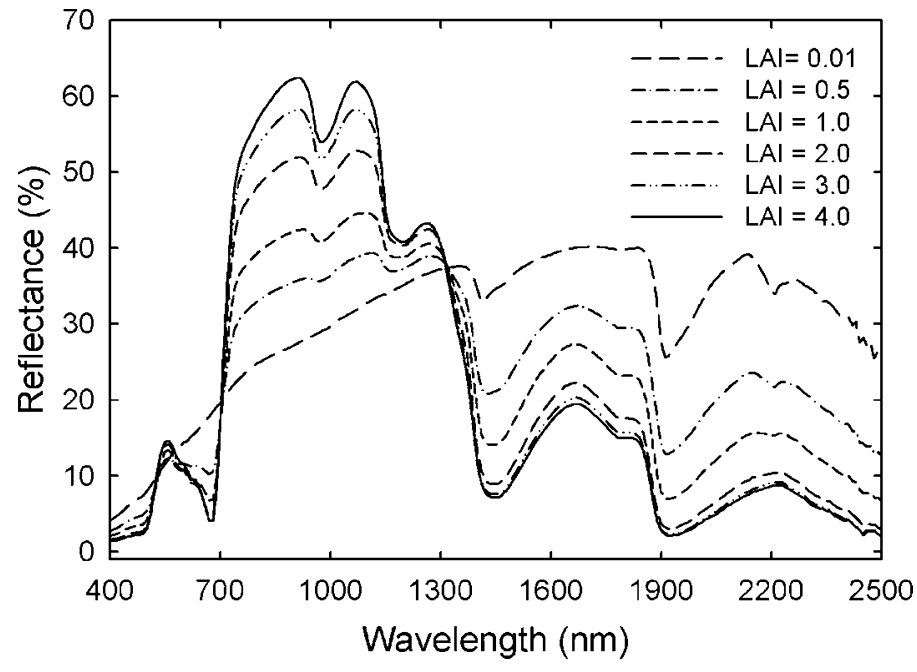

Figure 3. Scattering by Arbitrarily Inclined Leaves (SAIL) model simulations of canopy spectral reflectance for various Leaf Area Indices (LAI). Canopy proportions were $25 \%$ leaf spurge flower-bracts in the top canopy layer, 25\% leafy spurge leaves in the bottom canopy layer, and $50 \%$ grasses in the bottom canopy layer.

\section{RESULTS}

\section{Vegetation Indices}

All of the vegetation indices were significantly correlated with the measured cover of flowering leafy spurge at the 0.05 level of significance for the prairie cover type $(t$ test in simple linear regression). The $G / R$ had the best correlated index for the AVIRIS image $\left(R^{2}=0.23\right.$; Fig. $\left.2 \mathrm{~A}\right)$, the ETM+ image $\left(R^{2}=\right.$ 0.24 ; Fig. 2B), and the SPOT 4 image $\left(R^{2}=0.26\right.$; Fig. $\left.2 \mathrm{C}\right)$. The $R^{2}$ were $0.12,0.16$, and 0.19 for NDVI and spurge cover for the AVIRIS, ETM+, and SPOT 4 images, respectively (data not shown). Finally, the $R^{2}$ were $0.05,0.12$, and 0.19 , respectively, for the GNDVI. The slopes of vegetation indices versus spurge cover were not significantly different from 0 for the woodland cover type (data not shown). These results show there is little predictive power using vegetation indices to estimate the amount of flowering leafy spurge cover.

\section{Canopy Reflectance Modeling}

The SAIL model was designed to show the importance of LAI to the canopy reflectance spectrum (Verhoef 1984). At very low LAI, the simulated canopy reflectance spectrum from the SAIL model was similar to the input bare-soil reflectance spectrum, and at high LAI, the simulated canopy spectrum was similar to green leaves (Fig. 3). The increase of near-infrared reflectance was not linearly related to the increase in LAI. Simulated green reflectance changed little and simulated red reflectance decreased somewhat with an increase in LAI (Fig. 3).

In a simple mixture of leafy spurge leaves and grasses with a constant total LAI, simulated near-infrared reflectance increased with increased cover of leafy spurge (Fig. 4). The increase in near-infrared reflectance was due to the different leaf angle distributions of leafy spurge (planophile) and grasses (erectophile). The increase in simulated near-infrared reflectance for an increase in leafy spurge cover was found at different LAI. However, because near-infrared reflectance

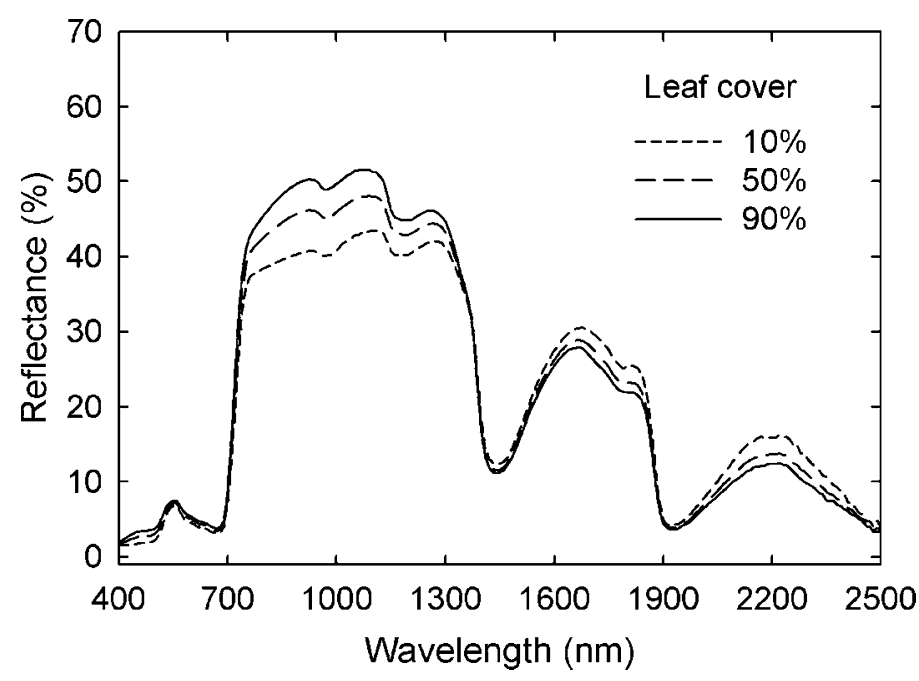

Figure 4. Scattering by Arbitrarily Inclined Leaves (SAIL) model simulations of canopy spectral reflectance for various proportions of leafy spurge leaf cover and grasses. Total Leaf Area Index (LAI) was 1.0.

increases with total LAI (Fig. 3), areas of grasses with high LAI and no leafy spurge cannot be distinguished from areas with low LAI and leafy spurge. In a similar set of simulations with simple mixtures of leafy spurge leaves and other forbs (planophile leaf angle distribution), there were no differences in simulated near-infrared reflectance (data not shown). These simulations indicate that under a highly restricted set of conditions, nonflowering leafy spurge may be remotely sensed using only near-infrared reflectance because of the different leaf-angle distributions between leafy spurge and grasses.

In a three-way mixture of leafy spurge flower bracts, leafy spurge leaves, and grasses, the simulated reflectance significantly increased in the green wavelengths with increasing cover of flower bracts of leafy spurge (Fig. 5). The increase in green reflectance was also simulated for three-way mixtures with forbs (data not shown). Therefore G/R may indicate the amount of cover by the flower bracts of leafy spurge.

For a three-way mixture of forbs, leafy spurge leaves, and leafy spurge flower bracts, the simulated G/R increased with increased cover of leafy spurge at low LAI but the response was less at high LAI (Fig. 6A). However, for a three-way mixture of grasses, leafy spurge leaves, and leafy spurge flower bracts, the trend of the simulated G/R depended on LAI (Fig. 6B). At low LAI, increasing cover of the flower bracts caused an increase in $\mathrm{G} / \mathrm{R}$, whereas at high LAI, increasing cover caused a decrease in G/R (Fig. 6B). This reversal was caused by the interactions between leaf angle distribution and LAI. Most grass canopies with or without leafy spurge have relatively low LAI. Thus, the ability of G/R to estimate the amount of flowering leafy spurge cover will depend on the total leaf area index and the type of co-occurring vegetation. Under controlled conditions, G/R is the best index for detection of flowering leafy spurge, but as indicated by the AVIRIS, Landsat ETM+, and SPOT 4 imagery, detection of leafy spurge using vegetation indices is problematic. 


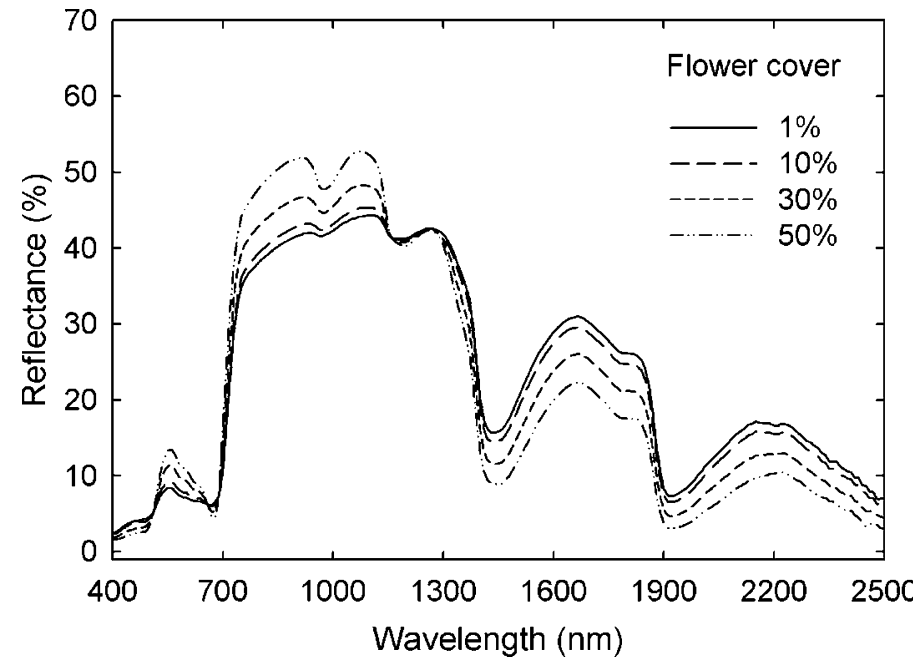

Figure 5. Scattering by Arbitrarily Inclined Leaves (SAIL) model simulations of canopy spectral reflectance for various proportions of leafy spurge flower-bract cover with leafy spurge leaves and grasses. Total Leaf Area Index (LAl) was 1.0: the proportion of leafy spurge leaves was equal to the proportion of flower bracts.

\section{DISCUSSION}

Leaf spectral differences are usually easy to distinguish visually, with the expectation that it should be just as easy to detect these differences with remote sensing. Flowering leafy spurge is detectable by visual interpretation of aerial photographs (Everitt et al. 1995; Anderson et al. 1999), so it was expected that multispectral data could be used to estimate the amount and distribution of flowering leafy spurge regionally. Therefore, it was surprising that the correlations of vegetation indices with leafy spurge cover for the Landsat 7 ETM+ and SPOT 4 multispectral sensors were so weak.

If the comparison was simply between hyperspectral (narrow band) and multispectral (broad band) imagery with similar pixel sizes, then there was no advantage using vegetation indices with hyperspectral imagery. However, with the AVIRIS data analyzed using the MTMF algorithm (Parker Williams and Hunt 2002), the fractional abundance of leafy spurge was highly correlated to the measured cover of leafy spurge for both the prairie $\left(R^{2}=0.79\right)$ and the woodland cover type $\left(R^{2}=\right.$ 0.57). These correlations were much better than the results obtained in this study using vegetation indices from the hyperspectral AVIRIS images; hence, the inability of the two multispectral satellites to detect leafy spurge abundance was not due to the large pixel sizes or the small number of bands. The advantage of hyperspectral imagery derives from the availability of advanced algorithms such as MTMF (Parker Williams and Hunt 2004); therefore, the information concerning leafy spurge was present in the hyperspectral imagery, and the vegetation indices tested here simply could not extract this information.

Since the spectral differences between leaves and flower bracts of leafy spurge were greatest at green wavelengths, and both the ETM+ and SPOT 4 sensors have green bands, correlation analyses with hyperspectral imagery to determine

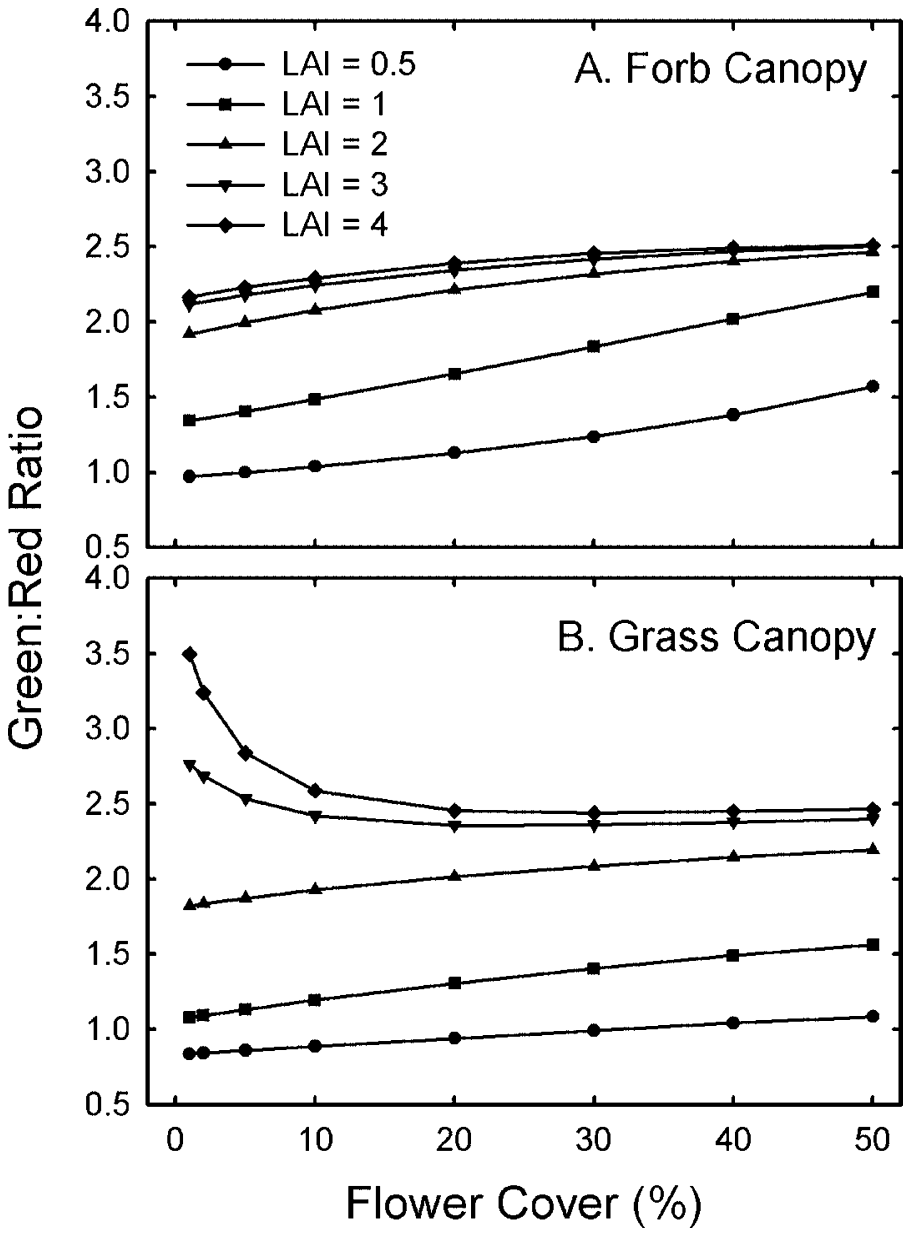

Figure 6. Scattering by Arbitrarily Inclined Leaves (SAIL) model simulations of the green:red reflectance ratio versus cover of leafy spurge flower bracts, with leafy spurge leaves and $\mathbf{A}$, forbs or $\mathbf{B}$, grasses at various total Leaf Area Indices (LAI). Proportion of leafy spurge leaves was equal to the proportion of flower bracts.

the best band may not lead to better indices with multispectral sensors. As the SAIL model results indicate, there are many sources of variation within an image (LAI, leaf angle distributions of various species, soil background reflectance, and solar angle); therefore, a few bands (narrow or broad) may not effectively account for the variation. On the other hand, hyperspectral analyses using spectral unmixing also may not be able to differentiate among all of the species present (Price 1994).

With the SAIL model (or other canopy reflectance models), the conditions for positive and negative results can be explored by computer simulation. To run this or similar models, a large spectral library needs to be developed with leaf and flowers of invasive species, co-occurring foliage, and soil backgrounds (Hunt et al. 2004). Unlike spectral libraries of minerals, the natural variation in leaf morphology, phenology, and biochemistry makes it difficult to construct a comprehensive spectral library. However, the work in constructing a comprehensive spectral library is much less than field testing various methods for the remote sensing of leafy spurge and other invasive species over the entire range of conditions. 


\section{MANAGEMENT IMPLICATIONS}

Most studies of remote sensing follow a predictable path: define a problem, acquire an image, collect ground data, and analyze the image until an acceptable agreement is found between the ground data and the results of the image analysis. This path, followed by Parker Williams and Hunt (2002, 2004), is essentially exploratory, to find out what is possible. In this study, we found that remotely sensed indices may not be useful for estimating the amount of cover of flowering leafy spurge, as indicated by both model simulations and image data analysis. Unfortunately, negative results are seldom published in the literature, creating problems for managers attempting to use the same procedures.

\section{ACKNOWLEDGMENTS}

The authors thank Dr David J. Kazmer (USDA-ARS), Dr Ronald W. Marrs (University of Wyoming), and Dr Stephen T. Jackson (University of Wyoming) for discussions. We thank Ralph Roberts (USDA-ARS) for programming and creating the interface for the SAIL model.

\section{LITERATURE CITED}

AleXander, L. 1983. SAIL Canopy Model Fortran Software. Houston, TX: National Aeronautics and Space Administration, Lyndon B. Johnson Space Center, NASA Technical Report JSC-18899.

Anderson, G. L., E. S. Delfosse, N. R. Spencer, C. W. Prosser, and R. D. Richard. 2003. Lessons in developing successful invasive weed control programs. Journal of Range Management 56:2-12.

Anderson, G. L., C. W. Prosser, S. Hagar, and B. Foster. 1999. Change detection of leafy spurge infestations using aerial photography and geographic information systems. In: Proceedings of the 17th Biennial Workshop Color Aerial Photography and Videography in Resource Assessment. Bethesda, MD: American Society of Photogrammetry and Remote Sensing. p. 223-230.

BoARDMAN, J. W. 1998. Leveraging the high dimensionality of AVIRIS data for improved sub-pixel target unmixing and rejection of false positives: mixture tuned matched filtering. In: R. 0. Green [ED.]. Summaries of the Seventh JPL Airborne Earth Science Workshop. Pasadena, CA: NASA Jet Propulsion Laboratory. JPL Publication 97-1. p. 55-56.

Boardman, J. W., F. A. Kruse, and R. 0. Green. 1995. Mapping target signatures via partial unmixing of AVIRIS data. In: R. 0. Green [ED.]. Summaries of the Fifth JPL Airborne Earth Science Workshop. Pasadena, CA: NASA Jet Propulsion Laboratory. JPL Publication 95-1. p. 23-26.

Daughtry, C. S. T., C. L. Walthall, M. S. Kim, E. Brown de Colstoun, and J. E. McMurtReY, III. 2000. Estimating corn leaf chlorophyll concentration from leaf and canopy reflectance. Remote Sensing of Environment 74:229-239.

Everitt, J. H., G. L. Anderson, D. E. Escobar, M. R. Davis, N. R. Spencer, and R. J. ANDRASCIK. 1995. Use of remote sensing for detecting and mapping leafy spurge (Euphorbia esula). Weed Technology 9:599-609.

EveritT, J. H., D. E. Escobar, and M. R. Davis. 2001. Reflectance and image characteristics of selected noxious rangeland species. Journal of Range Management 54:A106-A120.
Everitt, J. H., C. Yang, D. E. Escobar, and M. R. Davis. 2002. Using remote sensing to detect and map invasive plant species. Annals of the Arid Zone 41: 321-342.

Gao, B.-C., K. B. Heidebrecht, and A. F. H. Goetz. 1993. Derivation of scaled surface reflectances from AVIRIS data. Remote Sensing of Environment 44:145-163.

Gao, B.-C., K. B. Heidebrecht, and A. F. H. Goetz. 1999. Atmosphere REMoval Program (ATREM) user's guide, version 3.1. Boulder, CO: University of Colorado, Center for the Study of Earth from Space (CSES), Cooperative Institute for Research in Environmental Sciences (CIRES). 29 p.

Gitelson, A. A., Y. J. Kaufman, and M. N. Merzlyak. 1996. Use of a green channel in remote sensing of global vegetation from EOS-MODIS. Remote Sensing of Environment 58:289-298.

Glenn, N. F., J. T. Mundt, K. T. Weber, T. S. Prather, L. W. Lass, and J. Pettingill. 2005. Hyperspectral data processing for repeat detection of small infestations of leafy spurge. Remote Sensing of Environment 95:399-412.

Green, R. O., M. L. EASTwOod, ANd 0. Williams. 1998. Imaging spectroscopy and the Airborne Visible/Infrared Imaging Spectrometer (AVIRIS). Remote Sensing of Environment 65:227-248.

Harsanyi, J. C. and C. Chang. 1994. Hyperspectral image classification and dimensionality reduction: an orthogonal subspace projection approach. Institute of Electrical and Electronics Engineers Transactions on Geoscience and Remote Sensing 32:779-785.

Hunt, E. R., JR., J. H. Everitt, J. C. Ritchie, M. S. Moran, D. T. Booth, and G. L. ANDERSON. 2003. Applications and research using remote sensing for rangeland management. Photogrammetric Engineering and Remote Sensing 69: 675-693.

Hunt, E. R., JR., J. E. McMurtrey III, A. E. Parker Williams, and L. A. Corp. 2004. Spectral characteristics of leafy spurge (Euphorbia esula) leaves and flower bracts. Weed Science 52:492-497.

O'Neill, M., S. L. Ustin, S. Hager, and R. Root. 2000. Mapping the distribution of leafy spurge at the Theodore Roosevelt National Park using AVIRIS. In: R. 0. Green [ED.]. Summaries of the Ninth JPL Airborne Earth Science Workshop. Pasadena, CA: NASA Jet Propulsion Laboratory. JPL Publication 00-18. p. 339-347.

Parker Williams, A. E. 2001. Biological control and hyperspectral remote sensing of leafy spurge (Euphorbia esula L), an exotic plant species in North America [dissertation]. Laramie, WY: University of Wyoming. $134 \mathrm{p}$.

Parker Williams, A. E. and E. R. Hunt, JR. 2002. Estimation of leafy spurge cover from hyperspectral imagery using mixture tuned matched filtering. Remote Sensing of Environment 82:446-456.

Parker Williams, A. E. and E. R. Hunt, JR. 2004. Accuracy assessment for detection of leafy spurge with hyperspectral imagery. Journal of Range Management 57:106-112.

Price, J. C. 1994. How unique are spectral signatures? Remote Sensing of Environment 49:181-186.

Rouse, J. W., R. H. HaAs, J. A. Schell, and D. W. Deering. 1974. Monitoring vegetation systems in the Great Plains with ERTS. In: S.C. Freden, E.P. Mercanti, and M. Becker [EDS.]. Third Earth Resources Technology Satellite1 Symposium. Volume I: Technical Presentations, NASA SP-351. Washington, DC: National Aeronautics and Space Administration. p. 309-317.

RSI. 1999. ENVI, The Environment for Visualizing Images, user's guide, version 3.4. Boulder, CO: Research Systems, Inc. 930 p.

TuelleR, P. T. 1989. Remote sensing technology for rangeland management applications. Journal of Range Management 42:442-453.

TuelleR, P. T. 1995. Remote sensing in the management of rangelands. Annals of the Arid Zone 34:191-207. 